compared with 26.6 per cent in $1958-59 ; 50.3$ per cent were in lodgings and 22.7 per cent at home, but these proportions vary widely between men and women and between institutions.

The proportion of assisted students was 82.4 per cent, compared with 80.5 per cent in 1958-59 and 71.9 per cent in $1953-54$, ranging from 93.6 per cent in Wales, 89.0 per cent in English universities, excluding those at Oxford, Cambridge and London, to 73.4 per cent for Scotland. Full-time teaching and research staff increased to $11,474(10,823$ in 1958-59) and 25.6 per cent are now in pure science, 15.0 per cent in technology and 17.3 per cent in modicine.

Of the recurrent income of $£ 59,800,092$ ( $£ 52,273,306$ in 1958-59), $£ 43,170,107$ was from Parliamentary grants $(72 \cdot 2$ per cent), $£ 5,990,466$ from fees (10 per cent), £1,731,106 (2.9 per cent) from endowments,
$£ 1,533,673$ (2.6 per cent) from local authority grants, $£ 451,328$ from donations and subscriptions, and $£ 4,730,590$ from payments for research. Nonrecurrent Treasury grants amounted to $£ 19,852,747$, an increase of $£ 3,298,264$ on the previous year, and of this, $£ 13,839,308$ was spent on building work, $£ 1,914,375$ on professional fees, $£ 2,966,333$ on furniture and equipment and $£ 1,132,731$ on site and property purchases. Of the recurrent expenditure of $£ 58,505,072-$ an increase of $£ 3,978,797$ on that for the period 1958-59-6.8 per cent was spent on administration, $44 \cdot 0$ per cent on salaries and superannuation of teaching staff, 11.1 per cent on departmental wages, 13.9 per cent on departmental and laboratory maintenance, $3 \cdot 6$ per cent on repairs and maintenance of buildings and $\mathbf{9 \cdot 7}$ per cent on rates, insurance, heat, light, etc Expenditure on libraries, at $£ 2,350,294$, remained at $4 \cdot 0$ per cent of the total.

\title{
HEALTH SERVICES IN SMALL FACTORIES
}

A CONFERENCE on "Health Services in Small Factories" was convened jointly by the World Health Organization Regional Office for Europe and the International Labour Organization at Dun Laoghaire, Dublin, Ireland, during May 2-16 (WHO Chronicle, 15 , No. 9 ; 1961) The forty participants in the conference included medical officers, officials from Ministries of Labour, and representatives of employers' and workers' organizations from more than twenty countries.

Between 80 and 90 per cent of factories in most European countries employ less than 100 workers. Of the 220,000 factories in the United Kingdom, 150,000 employ 10 or fewer workers; more than a million people work in factories employing 25 or less, the number of such factories having nearly doubled in the past twenty-five years. In Italy, 95 per cent of industrial plants have less than 100 workers, in Switzerland 90 per cent, in Belgium 96 per cent, in Denmark 99 per cent, and in Sweden 92 per cent.

While the problem of providing health services in large factories in Europe is well on the way to solution even though different methods are used in different countries, the smaller factories in most countries of Europe do not have health services on or near their premises. The risks to which their workers are exposed are certainly not less than in the larger factories and in many cases are greater, since the working environment in terms of atrnosphere, ventilation and layout is considerably poorer.

Instruction in special hazards and supervision and training in handling dangerous materials, such as toxic chemicals or radioactive isotopes, are less efficient as a rule than in large factories. While periodic medical examinations are compulsory for workers in certain dangerous trades, there are usually no medical facilities within the factory beyond a first-aid box-the foreman is often in charge of this, but he is usually untrained in health matters.

There was general agreement among the participants in the conference that the provision of health services to these small undertakings is a real and urgent need, but there was less agreement about how to provide them. Among the difficulties are the diversity and dispersion of factories, which may be scattered over considerable distances. It is feasible for a doctor to provide health care for 3,000 workers in one factory, but not for thirty factories each with 100 workers. The cost of an autonomous health service is prohibitive for the small employer, and health hazards are often not understood or appreciated by employers and employees.

The conference discussed schemes now being tried out in various parts of Europe to provide health services for small factories. Four main tendencies are discernible.

In Czechoslovakia and in eastern Europe as a whole, these occupational health services are provided as part of a general programme of health protection covering both curative and preventive medicine and organized by the State.

In France, the Ministry of Labour is responsible for implementing general regulations on hygiene and security. Employers are obliged to set up health services which, for the majority of small factories, take the form of inter-factory services. The responsibilities of the physicians in these services are, in principle, the same as those of all industrial medical officers, that is, they are entrusted with preventive medicine, treatment being provided only in emergencies and for accidents.

In Italy, health services in small factories are mainly the concern of the National Institute for the Prevention of Accidents, which has some thirty branches scattered throughout the country.

In the Netherlands, the United Kingdom and Scandinavia, inter-factory occupational health services are provided on a voluntary basis, generally by means of a non-profit-making body on which doctors, employers and workers are represonted. Organizations of this type show a tendency to grow in size and popularity as new factories join the ser. vice, and to extend to other areas. Their role is mainly preventive ; but in some casos, they provide treatment also.

In a separate statement, the employers' representatives attending the Conference declared that, while agreeing that medical services in small factories should essentially be preventive, they nevertheless felt that these services should be encouraged to provide other treatment as well as emergency treat. ment. The advantages to be gained are a more efficient use of man-power, an increase in production 
(since workers would not lose so much time visiting hospitals for treatment) and improved morale. They stressed their opinion that such services should be organized on a voluntary basis.

The representatives of the workers' organizations welcomed the important developments now taking place in the field of health supervision for their members, though many of them considered that progress in this field was still too slow. It was their opinion that, by accepting the goal of occupational health services for all workers, the International Labour. Organisation has opened an important chapter in the history of occupational health.

\section{UNIVERSITY OF SUSSEX}

$\mathrm{T}$ HE first prospectus * of the University of Sussex describes the origins of the University since it was first promulgated in 1911, the way in which it has been constituted, proposed developments and the kind of administrative and teaching and research arrangements which are being made for students.

Courses leading to degrees in the Faculty of Arts and Social Studies will bo organized and pursued in a a different way from that followed in other British universities. The Faculty will be divided not into departments concerned with particular academic disciplines but into schools of study where different specialisms will be studied in relation to each other.

In 1962-63 there will be three such schools--the School of Social Studies, the School of English and American Studies, and the Sehool of European Studies. A School of Afro-Asian Studies will follow later. Each School will have a dean at its head. In addition, there will be professors and lecturers in particular subjects. The schools will not be superdepartments, and the same subject may be studied in more than one school.

Details of the science curriculum are still under consideration. It is intended to provide degree courses which will prepare students not only for careers as professional scientists, in the academic

* The University of Sussex. Prospectus, 1961-62. Pp. 26+2 plates. (Brighton: The University of Sussex, 1961.). world, in industry, and in Government scientific establishments, but also for careers as teachers, and in industrial, commercial and public administration. There will be a three-year course in natural science, leading to a classified honours degree. During this course students will study three subjects chosen from pure mathematics, applied mathematics, physics, chemistry, and biology. In addition, the curriculum will require some study (which will be examined) of the history of science and of the impact of science on society.

For a limited number of selected students, there will be a second honours course lasting a year, in which one science only will be studied, and a successful candidate will be awarded classified honours in that subject. The student who has completed this further course will thus have a specialized knowledge of a single science, and some understanding of the social sciences.

There will also be a course lasting three years in ongineering science. This will be a general course; it is not intended to provide specialized courses in civil, mechanical or electrical engineering.

During the years 1962-63 and 1963-64, only the subjects mathematics (pure and applied), physics and chemistry will be offered. It is hoped to begin courses in engineering in 1964 and in biology in 1965.

\section{METABOLISM OF THE HUMAN RED BLOOD CELL}

COME aspects of the metabolism of free fatty acids $\$$ by the human red blood cell in vivo have been studied by Dr. D. Mendelsohn of the Department of Pathology and Microbiology, University of the Witwatersrand, Johannesburg (S. Afric. J. Med. Sci., 20 ; Nos. 1 and 2; July 1961). Following the oral ingestion of glucose by a normal subject, an increase in erythrocyte-freo fatty acid concentration occurs, reaching a maximum in $1-1 \frac{1}{2} \mathrm{hr}$. In contrast, the diabetic patient shows a much smaller rise in red cell-free fatty acid during a glucose tolerance test; in many diabetic cases no increase could be detected at all. This defect in the diabetic erythrocyte could be corrected by the intravenous administration of insulin during the performance of a carbohydrate tolerance test.

Although the findings do not permit any definite conclusions to be drawn, it is suggested that the human red blood cell is able to synthesize lipid from carbohydrate in vivo. This faculty seems to be impaired in the human diabetic erythrocyte.

Mendelsohn has also examined the interrelation. ships of carbohydrate and lipid metabolism in the human erythrocyte in vitro; all the findings observed when investigating the metabolism of lipids by the human red blood cell in vivo have been reproduced in vitro. The results of the investigation suggest that under certain in vitro conditions, that is, in a phosphate buffer containing glucose and brilliant cresyl blue or methylene blue, the mature human red blood cell is able to synthesize fat from carbohydrate. Any exchange of fat between red cell and serum which might have been expected to cause a rise in erythrocyte lipid-levels has been eliminated by incubating the cells in phosphate buffer instead of serum. The fact that normal red cells showed an increase in total esterified fatty acid together with free fatty acid indicates that the rise in cell-free fatty acid was not due to lipolysis of complex lipids with subsequent release of fatty acids.

A much less noticeable rise in the level of free fatty acids was apparent in the erythrocyte of an insulindeprived diabetic patient when compared with a normal patient. Addition of insulin to the diabetic red cell suspension corrected this deficiency. It is suggested that under the in vitro conditions described, the mature human erythrocyte appears to be able to synthesize fat from carbohydrate whereas in the diabetic red cell this faculty is markedly impaired. Mendelsohn has also examined some of the mechanisms which might be responsible for the abnormal behaviour of the diabetic erythrocyte. 